\title{
Manoeuvring Simulation Methods Applied to Determine the Shape and Operational Condition of New Ports - Mielno Port Case Study
}

\section{Lucjan Gucma, Maciej Gucma, Rafat Gralak}

This paper presents a complex method of establishment of optimum design of sea ports with regard to navigational safety. Real-time simulation method was implemented in the presented study. The limited task real-time simulation model was created together with characteristic ship models and environment. The paper presents several stages of the research, such as the designing of the model, planning of simulation experiments and statistical analysis of results, The results are used as design guidelines for the small Polish sea port of Mielno which is currently under development.

\section{KEY WORDS}

$\sim$ Ship manoeuvring simulation

$\sim$ Safety of navigation

$\sim$ Port design

$\sim$ Breakwater optimization
Maritime University of Szczecin, Szczecin, Poland

e-mail: I.gucma@am.szczecin.pl

\section{INTRODUCTION}

The Marine Traffic Engineering (MTE) research team from the Maritime University of Szczecin (MUS) has been doing research in port design and optimization of water areas (Gucma, 2012; Gucma, 2009) since the 1970-ties. The study described in this paper focuses on the planning and design of the new Port of Mielno. It is one of several research studies conducted by the MTE team dealing with complex sea port planning and design (Computer simulation for new port design in Mielno, 2012). The main goals of the research studies were (PIANC, 2014):

1. The establishment of the optimum parameters of:

- the new sea port in the Mielno area with respect to shape, width and depth,

- $\quad$ the outer and inner port breakwaters with respect to their shape, taking into consideration wave height in the port;

- the turning points with respect to their shape and optimum depth;

- the berthing places in the inner port with respect to their shape, length, depth, maximum energy of ship contact, maximum speed of ship propeller and bow thruster streams on the bottom.

2. The establishment of the safe port operation requirements with respect to:

- admissible meteorological conditions for given kinds of ships and manoeuvres;

- other navigational conditions and limitations, like the presence of other ships at berths, the use of position fixing systems on approach, navigational markings, vessel traffic service. 
3. The establishment of manoeuvring procedures during berthing and unberthing for different kinds of ships and propulsion systems.

4. The establishment of under-keel clearance in keeping with the Monte Carlo method.

5. The establishment of ship's distance from the most dangerous objects.

6. Carrying out the most typical emergency runs (typical failures on entrance) and describing the necessary emergency action for captains.

Mielno Port is a small beach fishing port on the west coast of Poland, situated between the Baltic Sea and the sea lake of Jamno (Figure 1).

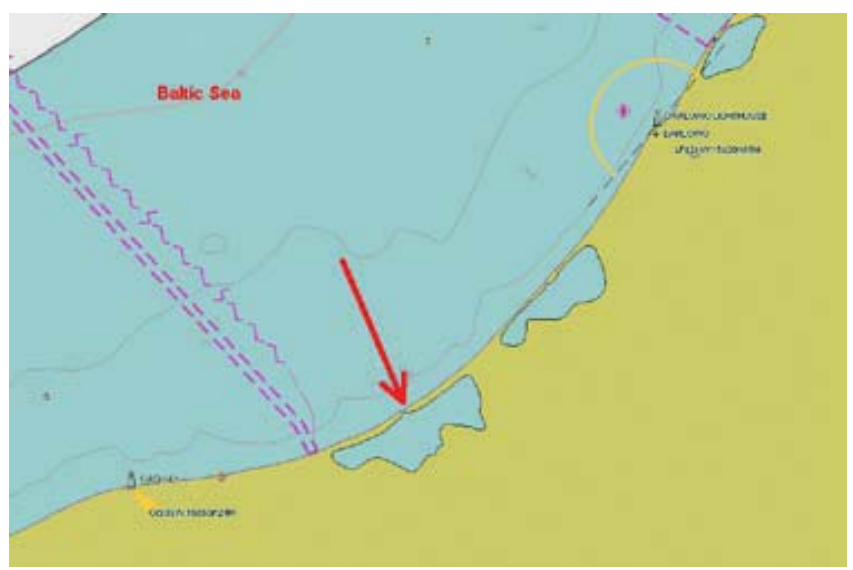

Figure 1.

Planned location of Mielno Port.

The typical Baltic sea small passenger ship, having the length of $L=60 \mathrm{~m}$ (Figure 2), was chosen as a characteristic ship ( $\mathrm{m} / \mathrm{f}$ Design) in the design stage of the new Mielno Port in the presented study, after the investors' economic analysis and based on their needs. The most important parameters of the design ship are presented in Table 1.

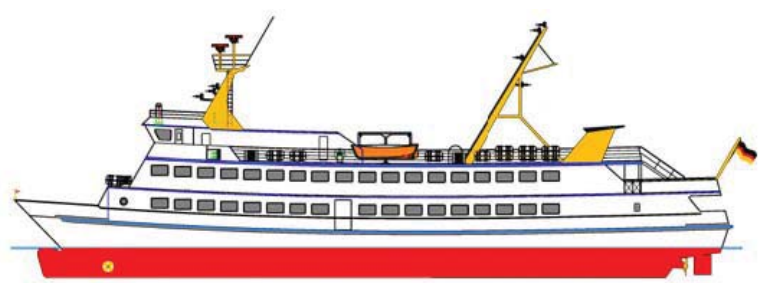

Figure 2.

General arrangement of $\mathrm{m} / \mathrm{f}$ Design (based on plans of $\mathrm{m} / \mathrm{f}$ Adler Dania).
Table 1.

Main parameters of design passenger ship $(\mathrm{L}=60 \mathrm{~m})$ operated in the Baltic Sea area.

\begin{tabular}{ll} 
Parameter & m/f Design \\
\hline Length - LOA & $60 \mathrm{~m}$ \\
\hline Breadth & $12 \mathrm{~m}$ \\
\hline Draft & $2.5 \mathrm{~m}$ \\
\hline Machinery & total $2 \times 1.200 \mathrm{~kW}$ at $900 \mathrm{rpm}$ \\
\hline Propeller & 1 variable pitch propeller \\
\hline Propeller & diameter $=1.83 \mathrm{~m}$ at $\mathrm{rpm} 360$ \\
\hline Speed & approx. $18 \mathrm{kn} .($ at $90 \%)$ \\
\hline Rudder & $\begin{array}{l}1 \times 35 \text { deg. } / \text { area }=2.7 \mathrm{~m}^{2} / \\
\text { conventional }\end{array}$ \\
\hline Bow thruster & $150 \mathrm{~kW}$ \\
Lateral wind area & approx. $500 \mathrm{~m}^{2}$ \\
\hline
\end{tabular}

\section{THE ASSUMPTIONS BEHIND MIELNO PORT DESIGN}

The most important goal of Mielno Port design is to provide access to passenger ships up to $60 \mathrm{~m}$ in length and enable future port development to accommodate cargo and fishing vessels (Computer simulation for new port design in Mielno, 2012). The most important design restrictions are as follows (Figure 3):

1. to design a sea port with two breakwaters, inner and outer (entrance) port, well-sheltered from typical weather conditions,

2. to design at least one turning point inside the new port,

3. to create at least 4 berthing places for design ships,

4. to test and validate at least TWO alternative port designs made by two independent design teams ( $\mathrm{S}$ and $\mathrm{B}$ team).
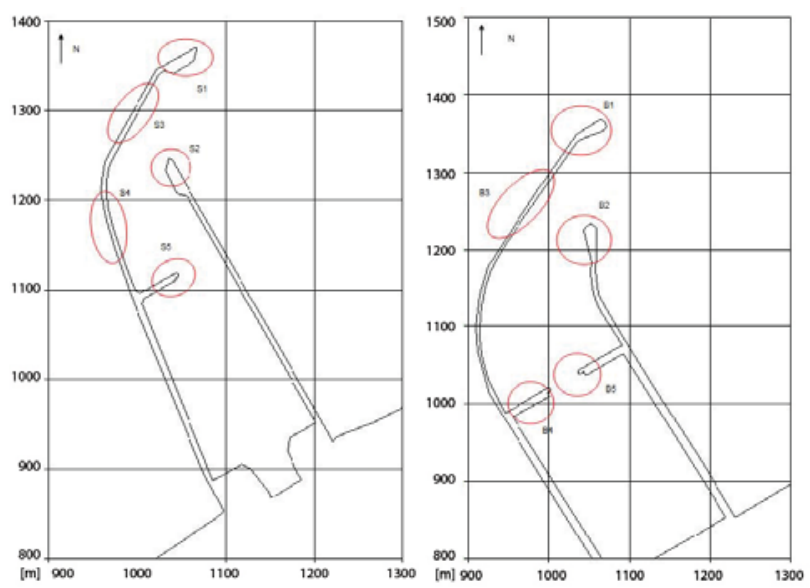

Figure 3

Two design alternatives for Mielno Port (S Design - upper and B Design - lower) with critical points. 


\section{METHODS APPLIED}

The real-time simulation interactive method with captains and pilots engaged in ship manoeuvring trials was applied. This method is thought to be most reliable and suitable for this kind of research studies (Gucma, 2005). MTE research team possess several kinds of manoeuvring simulators: from limited task simulator with 2D display to modern full-mission simulator with 3D display and real control systems.

\subsection{Real-time simulation method - limited task simulator}

Two classes of hydrodynamic models used by the MTE team had limited task simulators. While first class models were used when only limited parameters were known (usually when non-existing ships or a general class of ships were modelled), second class models were used when detailed and exact characteristics of hulls, propellers and steering devices were known. Additionally, real manoeuvring characteristics were used for the validation of models. The model of $\mathrm{m} / \mathrm{f}$ Design used in the research was based on modular methodology in which all influences, like hull hydrodynamic forces, propeller drag and steering equipment forces, as well as given external influences, are modelled as separate forces, subsequently summed up as perpendicular, parallel and rotational forces.

The model is operating in a loop in which input variables are calculated instantly (settings and disturbances) as forces and moments acting on the hull, while momentary accelerations and

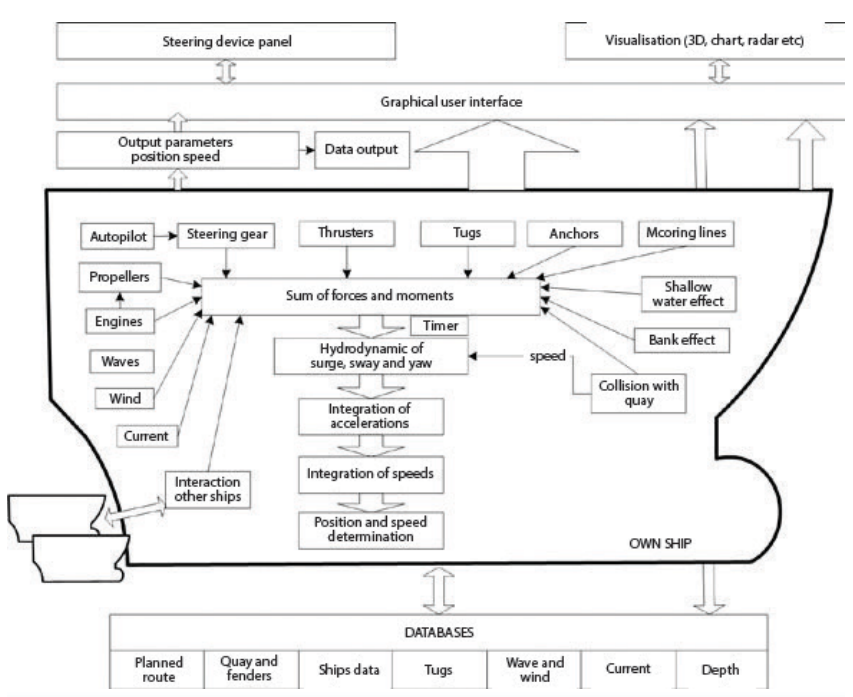

Figure 4.

The main functional diagram of the simulation model. speeds of movement surge, sway and yaw are evaluated. The most important forces acting on the model are:

- thrust of propellers;

- $\quad$ side force of propellers;

- $\quad$ sway and resistant force of propellers;

- bow and stern thruster forces;

- current;

- wind;

- $\quad$ ice effects (neglected);

- moment and force of bank effect (neglected);

- $\quad$ shallow water forces;
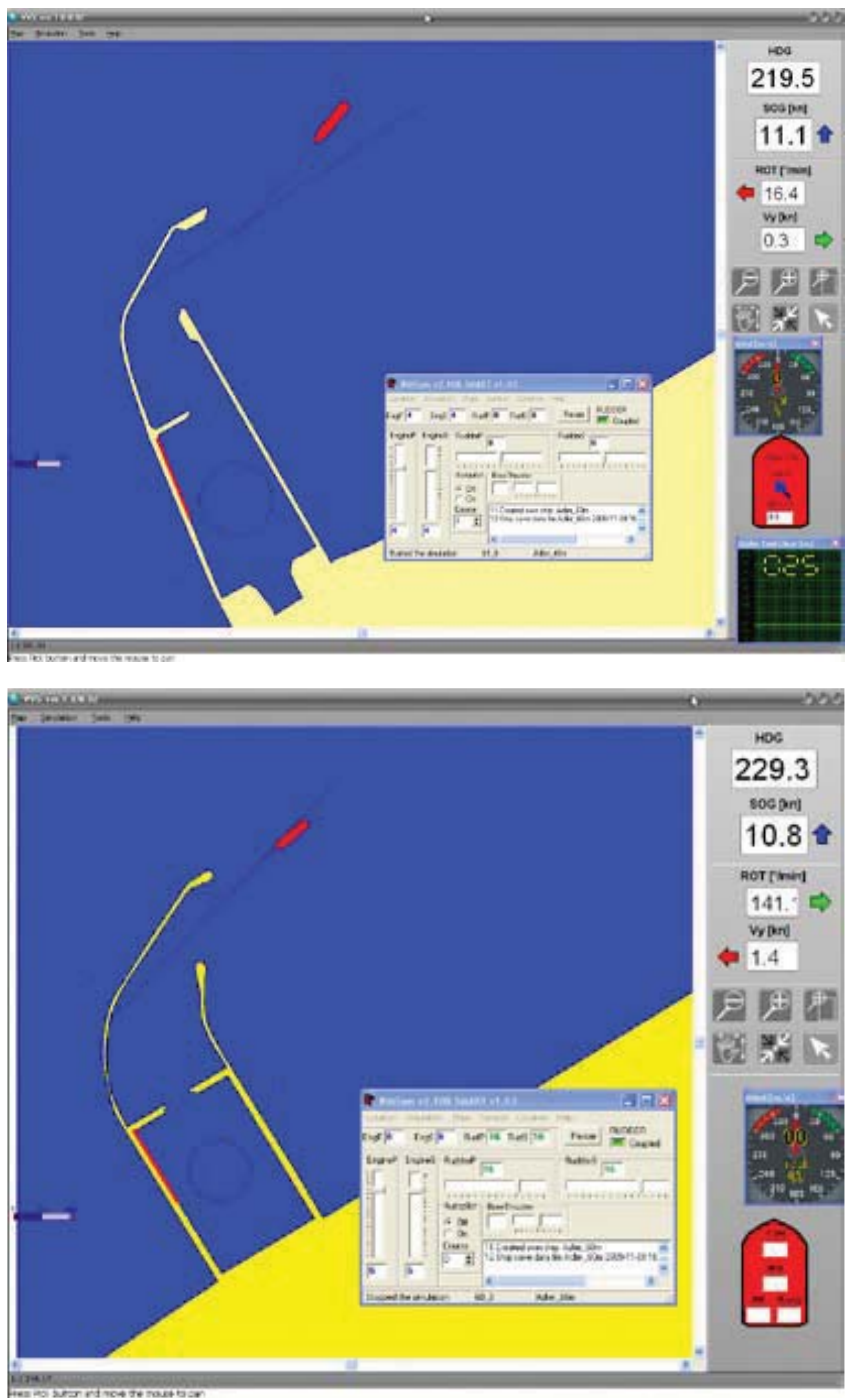

Figure 5.

Interface depicting simulation model Design turning at outer turning points S (left) and B (right) in Mielno port (limited task simulator). 
- $\quad$ mooring and anchor forces (neglected);

- $\quad$ reaction of the fenders and friction between fender and ship hull;

- $\quad$ tug forces (neglected);

- $\quad$ other, depending on the special characteristics of a ship's power and steering equipment.

The functional idea of the ship manoeuvring simulation model is presented in (Figure 4).

Interface of the model is typical 2D nautical chart - like interface in (Figure 5). The interface covers information on the ship's state (position, course-speed, yaw etc), quay and shoreline location, navigational markings, soundings, external conditions, tug and line control and control elements of the model. The model is implemented in Object Pascal with the use of the Delphi ${ }^{\mathrm{TM}}$ environment and Visual $\mathrm{C}^{\mathrm{TM}}$ with the use of the $\mathrm{C}++$ language.

Limited to the usual 3DOFs (the horizontal planar motion), the ship's movement over the ground (thus the so-called dynamic effect of the water current is introduced) is given by (Artyszuk, 2005):

$$
\left\{\begin{array}{l}
\left(m+m_{11}\right) \frac{d v_{x}^{g}}{d t}=\left(m+c_{m} m_{22}\right) v_{y}^{g} \omega_{z}+\left(m_{11}-c_{m} m_{22}\right) v_{y}^{c} \omega_{z}+F_{x} \\
\left(m+m_{22}\right) \frac{d v_{y}^{g}}{d t}=-\left(m+m_{11}\right) v_{x}^{g} \omega_{z}+\left(m_{11}-m_{22}\right) v_{x}^{c} \omega_{z}+F_{y} \\
\left(J_{z}+m_{66}\right) \frac{d \omega_{z}}{d t}=-\left(m_{22}-m_{11}\right)\left(v_{x}^{g}-v_{x}^{c}\right)\left(v_{y}^{g}-v_{y}^{c}\right)+M_{z}
\end{array}\right.
$$

$$
\frac{d x_{0}}{d t}=v_{N S}^{g}, \quad \frac{d y_{0}}{d t}=v_{E W}^{g}, \quad \frac{d \Psi_{0}}{d t}=\omega_{z}
$$$$
\left[\begin{array}{c}
V_{N S}^{g} \\
V_{E W}^{g}
\end{array}\right]=\left[\begin{array}{cc}
\cos \psi & -\sin \psi \\
\sin \psi & \cos \psi
\end{array}\right] \cdot\left[\begin{array}{c}
V_{x}^{g} \\
V_{y}^{g}
\end{array}\right]
$$

\section{where:}

$V_{x}, V_{y} g, \omega_{z}$ - represent ship surge, sway and yaw velocity over ground, $x_{\sigma^{\prime}} y_{\sigma^{\prime}} \psi$ - the position of Cartesian coordinates and heading, $m$ - ship mass, $m_{11^{\prime}} m_{22^{\prime}} m_{66}$ - added masses, $c_{m}-$ empirical factor, $F_{x^{\prime}} F_{y} M_{z}$ - external excitations (resultant/total surge, sway force and yaw moment), generally consisting of the following items (denoted by additional subscripts) and generally representing the functions of ship speed through water $\left({ }^{\prime} V_{w}{ }^{\prime}\right)$ :

$$
\left\{\begin{array}{l}
F_{x}=F_{x}\left(v_{x}^{w}, v_{y}^{w}, \omega_{z}\right) \\
F_{y}=F_{y}\left(v_{x}^{w}, v_{y}^{w}, \omega_{z}\right) \\
M_{z}=M_{z}\left(v_{x}^{w}, v_{y}^{w}, \omega_{z}\right)
\end{array}\right.
$$

$$
v_{x}^{w}=v_{x}^{g}-v_{x}^{c}, v_{y}^{w}=v_{y}^{g}-v_{y}^{c}
$$

$$
\left[\begin{array}{c}
V_{x}^{c} \\
V_{y}^{c}
\end{array}\right]=\left[\begin{array}{cc}
\cos \psi & \sin \psi \\
-\sin \psi & \cos \psi
\end{array}\right] \cdot\left[\begin{array}{cc}
\left|\vec{V}^{c}\right| & \cos \gamma_{c} \\
\left|\vec{V}^{c}\right| & \sin \gamma_{c}
\end{array}\right]
$$

where:

$\left|\vec{V}^{c}\right|$ and $\gamma_{c}$ represent the velocity and geographical direction of the water current (a uniform current by default).

The model is described in details by Artyszuk in (Gucma, 2013).

\subsection{Verification of the model}

The verification of a mathematical model, i.e. the quantitative assessment of its adequacy, is always carried out after the model is built and based on the conformity indicators of a ship's manoeuvring characteristics. The verification compares ship's manoeuvres by using comparative parameters:

- acceleration - distance and time for various operating modes of the main engine;

- $\quad$ stopping - distance, time, deviation from the original course for various ME working modes;

- $\quad$ turning ability (turning circle tests) - diameter, linear 
velocity and rate of the turn during turning;

- course stability (zigzag tests) - rudder response speed, maximum angle of deviation, yaw time, non-dimensional yaw period;

- turning ability with thrusters or engines, time to alter course by a specific value.

The validation of the model was carried out by using acceleration, breaking and circulation trials bearing in mind the influence of shallow water (Figure 6).

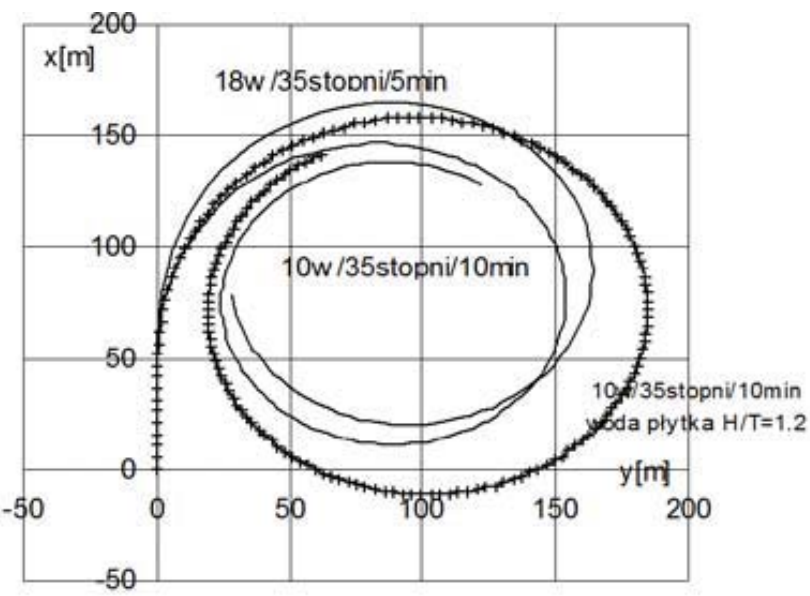

Figure 6.

Validation of the model (turning circles at different speeds compared with influence of shallow water) (Computer simulation for new port design in Mielno, 2012).

\section{STATISTICAL METHODS OF SIMULATION DATA PROCESSING}

Simulators are very widely used today. Hydrodynamic models are becoming more and more reliable. However, it should be made clear that conclusions cannot be drawn from the experiments conducted without efficient statistical data processing (Gucma, 2013). Usually a different kind of data processing analysis is applied when horizontal and vertical ship movement is considered.

\subsection{Safe manoeuvring areas - simulation result data processing method}

The safety horizontal area needed by navigators to perform manoeuvres is the most important factor [Gucma 2005, Irribaren 1999]. The assumption behind models of this type is that a ship is moving along predefined route $x$ (Figure 7.a) with the following probability of accident:
$P_{A W}=P_{S A / A} P\left(Y \geq y_{M A X}\right)=P_{S A / A} \int_{y_{\operatorname{Max}}}^{+\infty} f(y) d y$

where: $P_{S A / A}$ the conditional probability of serious accident, $f(y)-$ the distribution of ship's position, $y_{M A X}$ - distance from the centre of the waterway (route) to waterway edge.

The probability of serious accident $P_{S A / A}$ could be defined with the Heinrich ratio or a more detailed consequence analysis. One of the most important stages of accident probability evaluation is the statistical analysis of results. The probabilistic concept of a safe manoeuvring area is presented in Figure 7.a. The distribution is strongly dependant on waterway area arrangement, could be evaluated in simulations and validated in real-space experiments.

\section{RESEARCH PLAN}

The following conditions of manoeuvring have been considered:

- zero conditions (for validation and comparison of manoeuvring areas);

- $\quad$ wind $11 \mathrm{~m} / \mathrm{s}$ (lower limit of $\left.6^{\circ} \mathrm{B}\right)$;

- $\quad$ wind $17 \mathrm{~m}$

Two directions of wind have been considered:

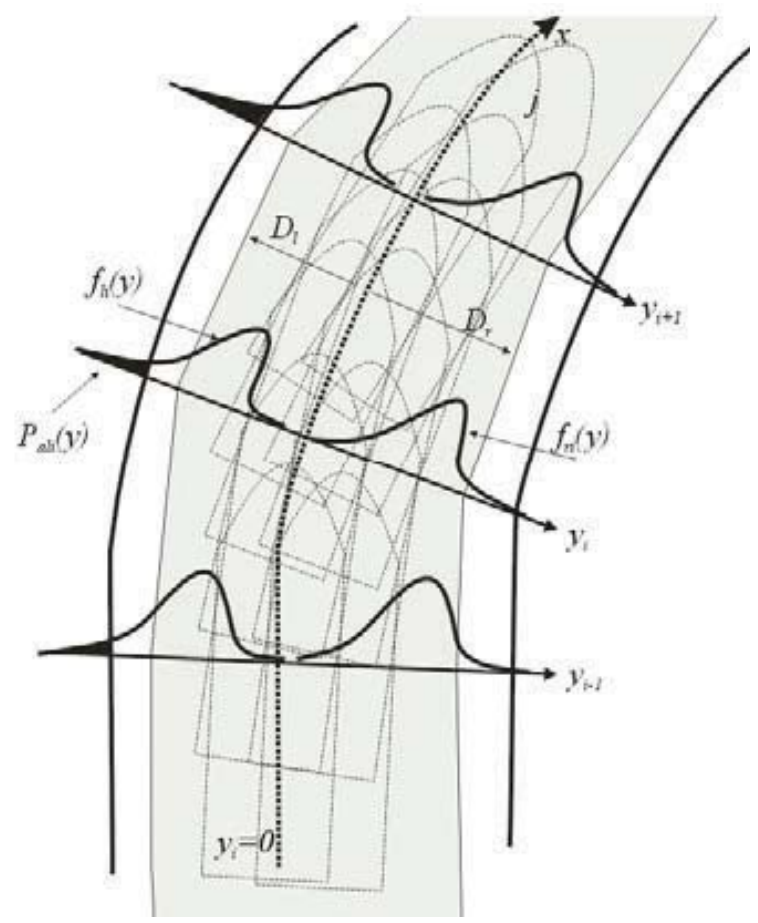


b)

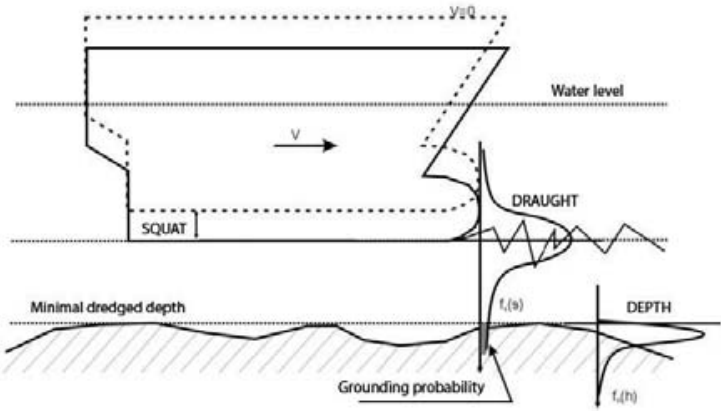

Figure 7.

The probabilistic concept of establishment of a safe manoeuvring area on the waterway (a) and the calculation of under-keel clearance (b).

- $\quad$ NW as the most difficult for entering the port.

- NNE as a problematic wind for stern directions, capable of causing entry problems due to the ship's stern moment of inertia.

The height of a significant wave depends on the wind and typical wind-wave conditions on the Baltic, presented in Table 2.

\subsection{Simulation series}

10 simulation series have been conducted, each for 13 to 14 ship passages (entrances only). A detailed plan of simulation passages is presented in Table 2. and the technique of manoeuvres is presented in (Figure 8).

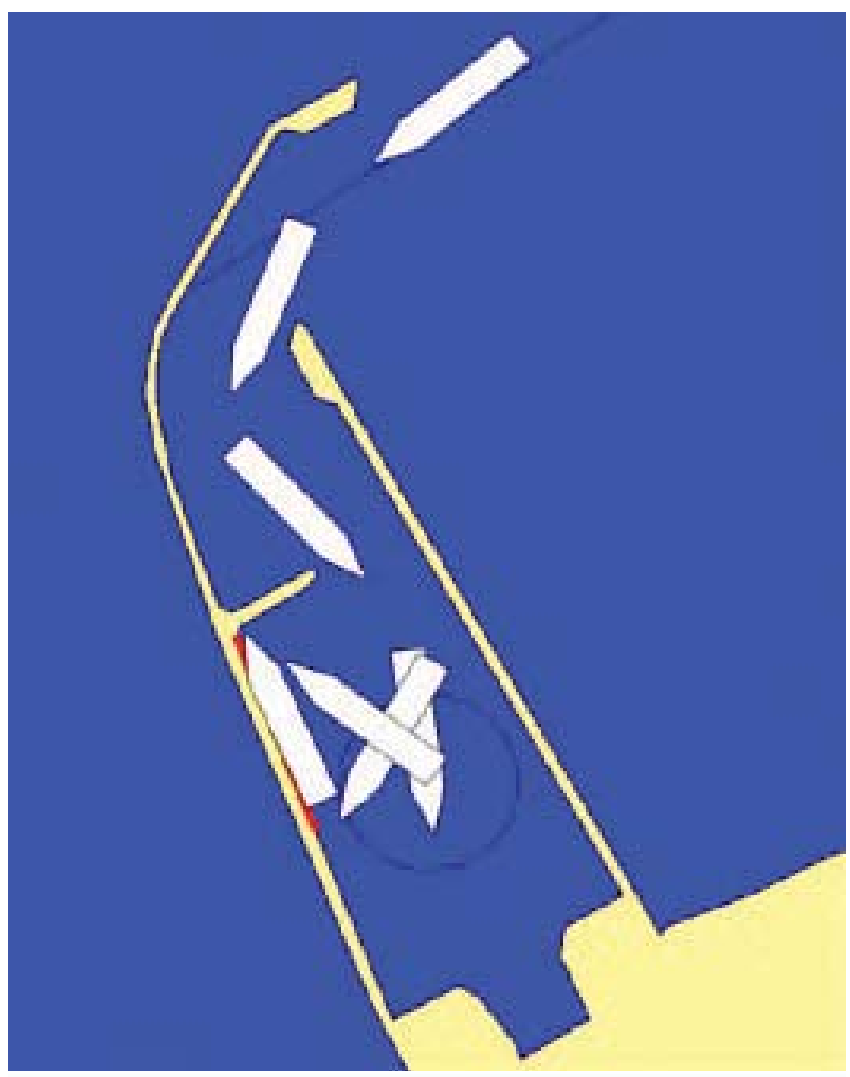

Figure 8.

Ship manoeuvre technique for the $\mathrm{S}$ and $\mathrm{B}$ design alternatives (entrance, immediate turning and mooring).

Table 2.

Detailed plan of simulations.

\begin{tabular}{|c|c|c|c|c|c|}
\hline No. & $\begin{array}{l}\text { Port design } \\
\text { alternative }\end{array}$ & Manoeuvre & Wind & Wave & $\begin{array}{l}\text { No. of simulation } \\
\text { passages }\end{array}$ \\
\hline 1 & \multirow[t]{5}{*}{$S$} & \multirow{10}{*}{ 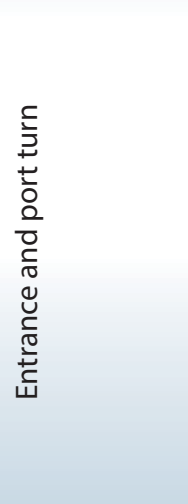 } & 0 & 0 & 14 \\
\hline 2 & & & NW 11 m/s (6B) & $0.9 \mathrm{~m}$ & 14 \\
\hline 3 & & & NW 17 m/s (8B) & $1.8 \mathrm{~m}$ & 14 \\
\hline 4 & & & NNE $11 \mathrm{~m} / \mathrm{s}$ & $0.9 \mathrm{~m}$ & 13 \\
\hline 5 & & & NNE $17 \mathrm{~m} / \mathrm{s}$ & $1.8 \mathrm{~m}$ & 13 \\
\hline 6 & \multirow[t]{5}{*}{ B } & & 0 & 0 & 14 \\
\hline 7 & & & NW 11 m/s (6B) & $0.9 \mathrm{~m}$ & 14 \\
\hline 8 & & & NW 17 m/s (8B) & $1.8 \mathrm{~m}$ & 13 \\
\hline 9 & & & NNE $11 \mathrm{~m} / \mathrm{s}$ & $0.9 \mathrm{~m}$ & 13 \\
\hline 10 & & & NNE $17 \mathrm{~m} / \mathrm{s}$ & $1.8 \mathrm{~m}$ & 13 \\
\hline
\end{tabular}




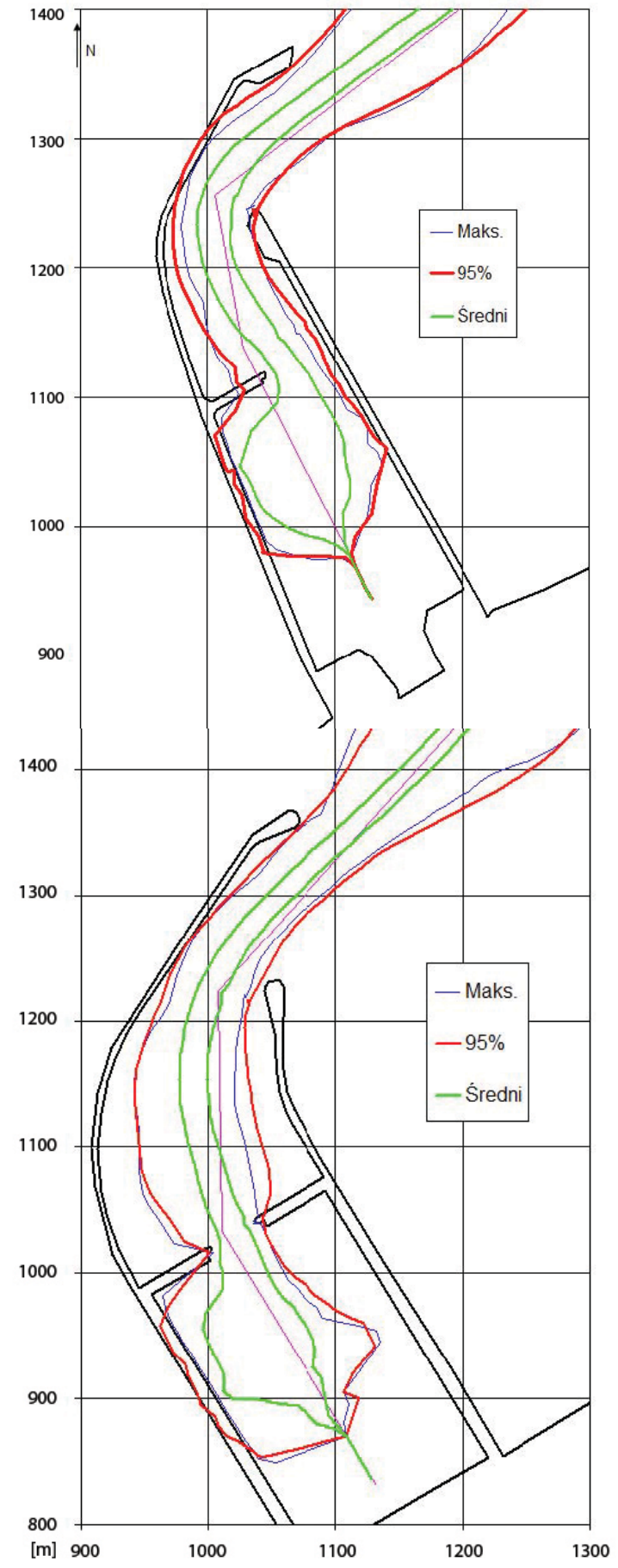

Figure 9.

Manoeuvring areas of Design ferry during entry with NNE $17 \mathrm{~m} / \mathrm{s}$ wind - comparing simulation series 5 and 10. The $95 \%$ confidence level presented in red (mean and maximum areas are blue and green) for $\mathrm{S}$ (upper) and B (lower) alternatives.

\section{RESULTS OF THE RESEARCH}

All simulation trials were conducted by skilled captains and pilots having experience with this kind of ships and manoeuvres. The simulation data were recorded and analyzed. Simulation results were analyzed on the basis of the following criteria:

- $\quad$ ship manoeuvring lane widths (horizontal safe manoeuvring area dimension),

- $\quad$ under-keel clearance (the Monte Carlo method);

- energy generated at the point of contact with berth structures,

- velocities of the propeller bottom stream,

- engine and rudder settings,

- $\quad$ probabilities of collision with given points,

- manoeuvre duration,

- emergency manoeuvres.

Only the results for the first criterion have been presented in this paper. The safe manoeuvring areas calculated with a $95 \%$ certainty are widely used in analysis. The results of one series, with the eastern wind of $20 \mathrm{~m} / \mathrm{s}$, are presented in Figure 9. Additionally, the maximum area, as the area of all ferry passages in a given simulation series, is presented.

The wave simulation analysis was made for alternative $B$ only. The results for significant wave height of $2 \mathrm{~m}$ from direction NNE are shown in (Figure 10).

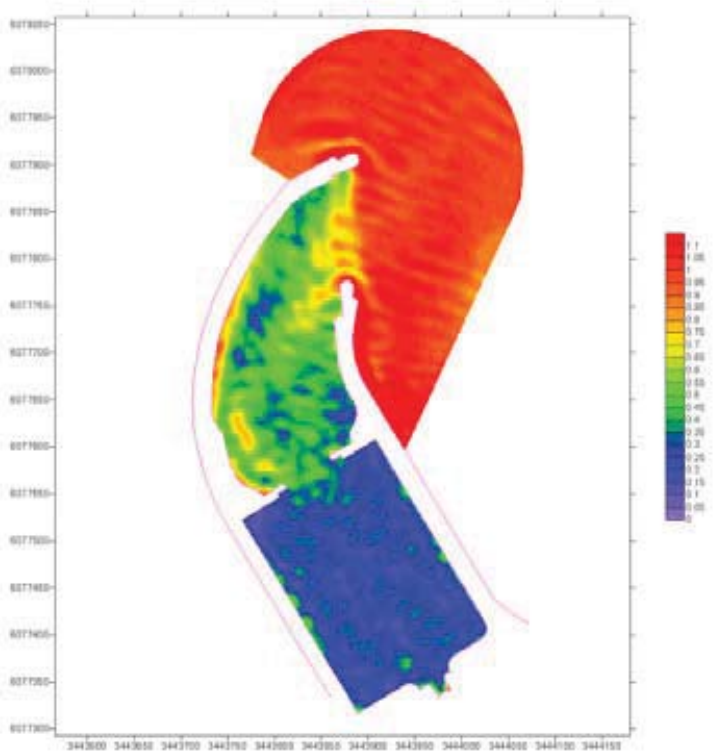

Figure 10

Numerical wave analysis for alternative B (wave system in the port, significant wave height outside the breakwaters NNE $2 \mathrm{~m}$ and period of $7 \mathrm{~s}$ ) (Study 2012, 2012). 


\section{CONCLUSIONS}

The presented complex study could be used for the development of guidelines for port design, operational limitations and risk assessment of new port and breakwater designs.

The efficient use of statistical data analysis for data processing and proper planning of simulation experiments, combined with good collaboration with designers and wave simulation specialists, are crucial for successful port design.

The conclusions pertaining to specific conditions required for the safe manoeuvring of passenger ship $\mathrm{m} / \mathrm{f}$ Design in Mielno Port are as follows:

- $\quad$ Since alternative $S$ is not acceptable in comparison with alternative $\mathrm{B}$, only alternative $\mathrm{B}$ is under consideration for further development (Table 3 shows differences between alternatives and necessary changes in given critical parts of the breakwaters - see Figure 3),

- $\quad$ Some minor modifications of alternative B (up to $5 \mathrm{~m}$ changes in the shape of the breakwater) are required (Table 3 ).

- $\quad$ Alternative B could be used as the final stage of Mielno Port design in the sense of navigational safety, when taking wave height inside the port into account.

- Acceptable wind conditions for safe entry of a $L=60 \mathrm{~m}$ long ferry are NNE $17 \mathrm{~m} / \mathrm{s}$ wind with wave height of $1.8 \mathrm{~m}$ outside the port.

Table 3.

Comparison of the required modifications of breakwaters in S and B alternative designs.

\begin{tabular}{|c|c|c|c|c|c|c|}
\hline \multirow[t]{2}{*}{$\begin{array}{l}\text { Simulation } \\
\text { series }\end{array}$} & \multirow[t]{2}{*}{ Alternative } & \multicolumn{5}{|c|}{$\begin{array}{l}\text { Additional width at critical points (see Figure } 3 \text { ) } \\
\qquad[\mathrm{m}]\end{array}$} \\
\hline & & S1 & S2 & S3 & S4 & S5 \\
\hline 1 & \multirow[t]{7}{*}{$S$} & 0 & 5 & 0 & 0 & 10 \\
\hline 2 & & 0 & 10 & 10 & 5 & 25 \\
\hline 3 & & 0 & 5 & 0 & 10 & 40 \\
\hline 4 & & 0 & 5 & 10 & 0 & 35 \\
\hline 5 & & 5 & 0 & 0 & 0 & 40 \\
\hline mean & & 1 & 5 & 4 & 3 & 30 \\
\hline max. & & 5 & 10 & 10 & 10 & 40 \\
\hline \multicolumn{7}{|c|}{$\mathrm{S}$ alternative - additional width of $\min .5 \mathrm{~m}$ required at the turning point } \\
\hline \multirow[t]{2}{*}{$\begin{array}{l}\text { Simulation } \\
\text { series }\end{array}$} & \multirow[t]{2}{*}{ Alternative } & & \multicolumn{4}{|c|}{$\begin{array}{l}\text { Additional width at critical points (see Figure } 3 \text { ) } \\
\qquad[\mathrm{m}]\end{array}$} \\
\hline & & B1 & B2 & B3 & B4 & B5 \\
\hline 6 & B & 0 & 0 & 0 & 2 & 0 \\
\hline 7 & & 0 & 5 & 0 & 2 & 0 \\
\hline 8 & & 0 & 2 & 0 & 0 & 0 \\
\hline 9 & & 0 & 0 & 0 & 5 & 5 \\
\hline 10 & & 0 & 0 & 5 & 5 & 5 \\
\hline mean & & 0 & 1.4 & 1 & 2.8 & 2 \\
\hline $\max$. & & 0 & 5 & 5 & 5 & 5 \\
\hline
\end{tabular}




\section{REFERENCES}

Artyszuk, J., (2005), Towards a Scaled Manoeuvring Mathematical Model for a Ship of Arbitrary Size, Scientific Bulletin, Maritime University of Szczecin.

Computer simulation for new port design in Mielno, (2012), Unpublished report, Maritime University of Szczecin.

Gucma, L., (2009), Wytyczne do zarządzania ryzykiem morskim (Guidelines for maritime risk assessment), Szczecin: Wydawnictwo Akademii Morskiej w Szczecinie.

Gucma, L., (2012), Zarządzanie ryzykiem w rejonie mostów usytuowanych nad drogami wodnymi $\mathrm{w}$ aspekcie zderzenia $\mathrm{z}$ jednostkami pływającymi (Risk assessment in bridge area in respect to ship-bridge collision), Wydawnictwo Akademii Morskiej w Szczecinie.

Gucma, L., (2005), Risk Modelling of Ship Collisions Factors with Fixed Port and Offshore Structures Maritime University of Szczecin.

Gucma, L. (ed.), (2013), LNG terminals design and operation, Navigational safety aspects, Szczecin: Marine Traffic Engineering.
Iribarren, J. R., (1999), Determining the horizontal dimensions of ship manoeuvring areas. PIANC Bulletin, no 100.

Ohtsu, K., Yoshimura, Y., Hirano, M., Tsugane, M. and Takahashi, H., (2006), Design Standards for Fairway in Next Generation, Asia Navigation Conference 2006, ICC Jeju, Korea, October 20-21, pp. 230-239.

PIANC, (2008), Innovations in navigation lock design, PIANC report 106, PIANC Secretariat General, Bruxelles.

PIANC, (2014), Harbour Approach Channels Design Guidelines, PIANC Report PIANC Secretariat General, Bruxelles.

Study 2012, (2012), Wave numerical analysis study in Mielno Port, Bimor, Szczecin.

USACE, (2006), Engineering and Design: Hydraulic Design Guidance for Deep-draft Navigation Projects, Engineer Manual EM 1110-2-1613, Washington DC. 